\title{
KEBIJAKAN REDAKSI KOMPAS TV MAKASSAR DALAM MENAYANGKAN BERITA
}

\author{
Nur Asrianti, Achmad Herman, Andi Akifah \\ Prodi Ilmu Komunikasi Universitas Tadulako \\ achmadherman@gmail.com
}

\begin{abstract}
An editor of electronic media has the authority to determine what news is appropriate to be displayed, and disseminated. Editor of Kompas TV has the right to display and not display a news, there is even news that can air more than once on a different day, there is news that does not show because there is news that aired first and the time is up for the news segment. Kompas TV Makassar also has several terms and conditions in assessing how feasible a news can be displayed so that it can become public consumption. Kompas TV Makassar has never feared the opinions of audiences when they played back the news that had been aired
\end{abstract}

Keywords: Editor, Displaying News, Kompas TV Makassar

\begin{abstract}
Abstrak
Seorang redaksi media elektronik memiliki kewenangan untuk menentukan berita apa yang layak ditampilakan, dan disebar luaskan. Redaksi Kompas TV memiliki hak untuk menayangkan dan tidak menayangkan sebuah berita, bahkan ada berita yang bisa tayang lebih dari sekali di hari yang berbeda, ada berita yang tidak tayang karena ada berita yang ditayangkan terlebih dahulu dan waktu sudah habis untuk segmen berita tersebut. Kompas TV Makassar juga mempunyai beberapa syarat dan ketentuan dalam menilai sebarapa layak sebuah berita dapat ditayangkan agar dapat menjadi konsumsi publik. Kompas TV Makassar tidak pernah takut akan pendapat khalayak apabila mereka memutar kembali berita yang telah tayang
\end{abstract}

Kata Kunci : Redaksi, Menayangkan Berita, Kompas TV Makasar

\section{Pendahuluan}

Sebelum menulis berita, yang perlu selalu diingat adalah format berita. Ini berarti, yang dilakukan pertama yaitu, menentukan format berita televisi yang digunakan, kemudian baru menulis naskah berita sesuai dengan format yang dipilih. "Broadcasting" dikenal istilah "Easy Listening Formula" memiliki arti yang didalamnya terdapat susunan kalimat yang dibuat, harus mudah didengar dan dicerna. Formula ini harus diterapkan oleh para "broadcaster" yang dalam istilah televisi, gaya bahasa yang digunakan merupakan gaya bahasa tuturan atau penyampaian yang dalam pengertian bahasa Inggrisnya disebut "Spoken language".

Dalam pembuatan berita diperlukan seorang redaksi, dimana ia yang menentukan berita apa, bagaimana yang 
layak ditampilkan, dan disebar luaskan. Redaksi Kompas TV memiliki hak untuk menayangkan dan tidak menayangkan sebuah berita, bahkan ada berita yang bisa tayang lebih dari sekali di hari yang berbeda, ada berita yang tidak tayang karena ada berita yang ditayangkan terlebih dahulu dan waktu sudah habis untuk segmen berita tersebut.

Kompas TV Makassar juga mempunyai beberapa syarat dan ketentuan dalam menilai sebarapa layak sebuah berita dapat ditayangkan agar dapat menjadi konsumsi publik. Pesan yang disampaikan melalui media massa terutama televisi, selayaknya memiliki dan menguasai sifat-sifat massa, sehingga dengan adanya memahami sifat medium ini proses komunikasi yang terjadi akan berjalan semakin efektif dan efisien dan pesan pun akan sampai pada komunikan semakin besar

\section{Tinjauan Pustaka}

\section{Komunikasi Massa}

Menurut Jay Black dan Frederick C. Whitney

menyebutkan

Masscommunication is a process whereby mass-produced message are transmitted to large, anonymous, and heterogeneous masses of receivers (komunikasi massa adalah sebuah proses di mana pesan pesan yang diproduksi secara massal/tidak sedikit itu disebarkan kepada massa penerima pesan yang luas, anonim dan heterogen). Menurut Severin dan Tankard (2007) dalam Rivers (2012: 90) bagaimana peliknya komunikasi massa, yang ditulis dalam bukuCommunication Theories, Origins, Metdhos, Uses, mengatakan sebagai berikut : "Komunikasi massa adalah sebagian keterampilan, sebagian seni, dan sebagian ilmu".

\section{Media Massa}

Ketika membahas komunikasi massa, maka di dalamnya terdapat lembaga atau institusi yang dikenal dengan media massa. Jadi keseluruhan secara umum media massa dapat dimengerti sebagai sumber pada berita atau pemberitaan dan sebagai sumber berita dan sebagai sumber hiburan. Ketika membahas media massa di dalamnya juga terdapat memuat pesan pesan yang penting seperti pesan-pesan yang bersifat persuasif yan mengantarkan audience pada pemahaman pendapat yang berdeda mengenai issue.

Menurut Hafied Cangara, arti media massa adalah merupakan alat yang digunakan dalam penyampaian pesan dari sumber (komunikator) kepada khalayak (penerima pesan) yang disampaikan melalui alat komunikasi mesin seperti surat kabar, film, radio dan televisi. Adapun fungsi utama media massa dalam 
arti saluran, memberikan informasi pada kepentingan khalayak, menyebarluaskan dan mengiklankan sebuah produk (Cangara, 2005: 122).

\section{Media Elektronik}

Pengertian media elektronik adalah media komunikasi yang di dalamnya memiliki alat alat elektronik, atau media elektronik. Iskandar, mendefinisikan, media komunikasi massa diantaranya adalah:
a). Radio
b). Film
c). Televisi
d). Internet

Media massa Televisi dimulai ketika sidang dewan keamanan PBB pada tahun 1946 yang ditayangkan melalui TV kabel (Bambang, 2000:82). Dalam media televisi daya tariknya bertumpu pada musik, kata-kata, suara sebagai kekuatan visual. Sehingga pengaruhnya lebih meresap.. Ketika kita menonton televisi, maka memerlukan perhatian penuh, dibandingkan radio yang bisa diselingi oleh kegiatan lain. Sebagai media elektronik, teleisi muncul terakhir yang pada akhirnya memiliki kekuatan bisnis yang besar di Indonesia. Media televisi memiliki kekuatan agenda setting dalam mempengaruhi penontonnya. Sebagai media elektronik, televisi memiliki daya tarik luar biasa melalui acaranya tersebut menyesuaikan dengan karakter Televisi dan pemirsa yang terpengaruh oleh Televisi (Wibowo, $1997: 1$ ).

\section{Struktur Berita dan Pembuatan Berita}

\section{Pada Media Elektronik}

Analisis berikutnya menurut Molotch dan Lester, (1974) dalam (Tohir, 2013: 15) memperhalus lukisan Lippman, tetapi wataknya yang esensial tetap utuh : berita adalah proses (pembuatan berita) menegosiasikan laporan yang bermakna tentang kejadian. Berita mencakup simbolisasi :

1). Kejadian sebagai peristiwa "tindakan tegas" yang mengisyaratkan "keadaan dengan segala kerumitannya yang bersimpang-siur",

2). Peristiwa sebagai bernilai berita melalui berita dan kisah berita - "buletin streotip yang menerbitkan isyarat", dan 3). Peristiwa yang bernilai berita sebagai bermakna bagi orang untuk membuat penyesuaian dalam kehidupannya "makna yang dikemukakan sendiri oleh pembaca setelah ia menurunkan makna itu dari pengalaman yang secara langsung mempengaruhinya".

\section{Kejadian sebagai Peristiwa}

Kejadian adalah segala sesuatu yang berlangsung di dunia, baik kita mengetahuinya ataupun tidak. Orang 
melakukan pekerjaan sehari-hari, pesawat terbang mengudara, mobil meluncur di jalan raya, dan seperti yang dilagukan oleh humoris Will Rogers, rumput tumbuh dan air mengalir.

Akan tetapi sekali-sekali, untuk meminjam judul novel bestseller Joseph Heller, "terjadi sesuatu" yang memecahkan kehidupan rutin yang normal, sesuatu yang tidak biasa, barangkali bahkan begitu luar biasa. Orang meninggal, pesawat terbang jatuh, mobil tabrakan, mobil tabrakan, serta kelaparan dan kekeringan. Segala seuatu tidak lagi rutin; situasi menjadi masalah.

Orang menginterpretasikannya sebagai peristiwa, sebagai bermakna dalam pengalaman mereka. Mereka menuntut lebih banyak informasi mengenai peristiwa ini sehingga mereka dapat menyesuaikan diri kepada kejadian nonrutin yang telah mendapat tambahan kepentingan.

\section{Peristiwa Sebagai Sesuatu yang Bernilai}

Pengertian peristiwa sebagai sesuatu yang bernilai memiliki arti ketika orang berpendapat informasi tentang peristiwa itu dianggap penting. Menurut Shibutani, informasi yang lebih atau informasi yang kurang penting yang dibutuhkan orang dalam melakukan penyesuaian terhadap keadaan yang berubah, sebuah berita akan dicari oleh seorang watawan kadang kadang dengan sebuah pengorbanan yang besar, hal ini diperlukan untuk memperoleh posisi dan kedudukan dalam sebuah dunia yang berubah dengan cepat.

Jurnalis masuk sebagai komunikator yang menciptakan kontruksi yang bermakna. Laporan reporter bukan kebenaran, juga bukan kabar angin, melainkan realitas yang disusun bagi tujuan yang praktis untuk menghilangkan ketakpastian dalam situasi nonrutin.

\section{Peristiwa bernilai berita sebagai kisah}

\section{berita}

Molotch dan Lester, (1974) dalam (Djamal dan Fachruddin, 2011: 97) menguraikan bagaimana suatu peristiwa mempunyai nilai berita. Prosesnya melibatkan tiga perangkat orang. Mereka adalah, pertama, orang-orang yang mempromosikan peristiwa untuk tujuan, yakni promotor. Kedua, ada orang yang mengumpulkan dan memilih informasi tentang peristiwa (orang yang memilih apa yang akan dilaporkan dan apa yang tidak), yaitu jurnalis. Dan ketiga, terdapat konsumen laporan ini - pembaca, penonton, dan sebaginya. Dengan menggunakan klarifikasi ini. Adapaun format berita televisi sebagai berikut: Reader (RDR), Voice Over (VO), Voice Over-Grafik (VO-Grafik), Voice Over - 
Sound on Tape (VO-SOT), Sound on Tape (SOT), Paket atau Package (PKG), Live On Tape (LOT), Live On Cam (Laporan Langsung), Visual News, Live by Phone, Phone Recorddan Vox Pop.

\section{Kebijakan Redaksional Media}

Menurut Henz Eulau dan Kenneth Previt, (1973) dalam (Tohir, 2013: 17) mendefinisikan bahwa sebuah kebijakan merupakan keputusan yang tetap, yang ditandai oleh kelakuan yang selalu berkesinambungan dan berulang-ulang pada mereka yang membuat sebuah kebijakan dan melaksanakannya. Pendapat lain dikemukakan oleh Marbun, (2003) dalam (Tohir, 2013:17) sebuah kebijakan Redaksional meliputi dua kata, yaitu kebijakan dan redaksional. Dalam kamus besar bahasa Indonesia, kebijakan merupakan rangkaian konsep dan asas yang menjadi garis besar serta dasar sebuah rencana dalam pelaksanaan suatu pekerjaan kepimimpinan dan cara bertindak: pernyataan, cita-cita, tujuan, prinsip, maksud sebagai garis pedoman untuk manajemen dalam usaha mencapai sasaran.

Tebba, (2005) dalam (Tohir, 2013:23) adanya kebijakan redaksional amenjadi sangat penting untuk sebuah media massa yang memungkinkan kelangsungan sebuah perusahaan., karena kebijakan redaksional merupakan pembeda antara media massa yang satu dengan media massa yang lainnya. Selain itu jika sebuah media massa tidak memiliki kebijakan redaksi, maka media massa tersebut dalam penyampaian berita-beritanya tidak akan konsisten. Hal ini ditandai dengan penyampaian sebuah berita yang selalu berubah-ubah. Hari ini menyuarakan dukungan terhadap kebijakan pemerintah, besoknya menyuarakan menentang terhadap kebijakan pemerintah. Sikap media seperti ini, dapat melunturkan kepercayaan khalayak pada media tersebut.

\section{Level Pada Konten Media Massa}

Teori tentang Hirarki Pengaruh isi media dikemukakan oleh Pamela J.Soemaker dan Stephen D. Reese (1996:60). Dalam teori yang dikemukakannya menyebutkan bahwa pengaruh terhadap isi dari suatu pemberitaan media disebabkan oleh pengaruh internal dan pengaruh eksternal..Menurut Shoemaker dan Reese terdapat beberapa level terkait dengan pengaruh isi media antara lain : pertama, adanya pengaruh dari individu pekerja pekerja media (individual level), yang kedua adalah pengaruh dari rutinitas media (media routines level), yang ketiga adalah, pengaruh dari organisasi media 
(organizatinal level), selanjutnya yang keempat adalah pengaruh dari luar media (outside media level), dan yang terakhir adalah pengaruh ideologi (ideology level).

Jika melihat uraian teori tersebut maka asumsinya adalah bagaimana pesan -pesan media yang disampaikan kepada khalayak luas adalah hasil dari pengaruh kebijakan internal organisasi media dan juga adanya pengaruh dari eksternal media itu sendiri. Pengaruh dari internal media massa tersebut berhubungan dengan kepentingan dari pemilik media, individu, dan wartawan sebagai pencari berita, dan rutinitas organisasi media sehari-hari. Adanya pengaruh faktor eksternal media yang ikut mempengaruhi konten media adalah munculnya para pengiklan, pangsa pasar, kontrol pemerintah, dan faktor eksternal lainnya.

Dalam teori ini akan terlihat seberapa besar hirarki pengaruh dalam sebuah berita pada tiap-tiap level yang diperkenalkan oleh Pamela J. Shoemaker dan Stephen D.Reese :

\section{Level Pengaruh Individu Pekerja Media}

Pengaruh individu sebagai pengaruh yang pertama pada sebuah pemberitaan di sebuah media. Arah pemberitaan suatu media dan unsur-unsur yang diberitakan tidak dapat dilepaskan dari faktor-faktor seorang wartawan atau reporter, karena dalam hal ini mereka terjun langsung mencari, mengumpulkan, dan membuat berita. Faktor pertama yang membentuk individu adalah latar belakang dan karakteristik seorang jurnalis dilihat dari segi pendidikan seorang jurnalis. Faktor kedua yang dapat membentuk faktor individual level adalah faktor kepercayaan, nilai-nilai dan perilaku pada seorang jurnalis. Faktor ketiga yang membentuk individu adalah profesionalitas dan kode etik yang diikuti oleh seorang wartawan dan reporter (Shoemaker dan Reese, 1996: 66).

\section{Level Rutinitas Media}

Level rutinitas media merupakan terkait dengan efek pada pemberitaan dilihat dari sisi rutinitas media. Ketika sebuah media rutin terbentuk oleh tiga unsur yang saling berkaitan yaitu sumber berita (suppliers), organisasi media (processor), dan aundiens (consumers). Ketiga unsur ini saling berhubungan dan berkaitan dan pada akhirnya membentuk pemberitaan pada sebuah media (Shoemaker dan Reese, 1996: 109-117).

\section{Level Pengaruh Organisasi Media}

Level ketiga dalam toeri hirarki pengaruh media adalah level organisasi media. Pembahasan tentang level pengaruh organisasi ini, biasanya membahas tentang kepemilikan. Titik 
fokus level ini adalah pada pemilik atau pemimpin media yang menentukan kebijakan sebuah media (Shoemaker dan Reese, 1996: 140-172).

\section{Level Pengaruh Luar Organisasi Media}

Level keempat dari teori hirarki pengaruh media adalah pengaruh dari luar organisasi media yang bisa disebut juga extra media level. Extra media level adalah pengaruh-pengaruh pada isi media yang berasal dari luar organisasi media itu sendiri. . Maka dari itu, setiap media harus memperhatikan isi berita yang disajikan agar tetap sejalan dengan faktor-faktor dari luar media dan untuk mempertahankan kelangsungan hidup media (Shoemaker dan Reese, 1996: 173).

\section{Level Pengaruh Ideologi Media}

Level yang terakhir pada teori hirarki pengaruh Pamela J. Shoemaker dan Stephen D. Reese adalah level pengaruh ideologi pada konten media. Berbeda dengan level pengaruh media sebelumnya yang tampak konkret, level idelogi ini abstrak. Level ini berhubungan dengan konsepsi atau posisi seseorang dalam menafsirkan realitas dalam sebuah media (Shoemaker dan Reese, 1996: 221-432).

\section{Metode Penelitian}

Penelitian ini menggunakan metode deskriptif kualitatif. Metode deskriptif bertujuan membuat deskriptif secara sistematis, faktual, dan akurat tentang fakta-fakta dan sifat-sifat populasi atau objek tertentu. Penelitian deskriptif hanya memaparkan situasi atau peristiwa, yaitu melalui penelitian survei atau penelitian observasional, sehingga dalam penelitian ini peneliti menggambarkan variabel demi variabel, mengumpulkan data melalui observasi dan suasana alamiah. (Krisyantono, 2006:68)

Untuk menyajikan data agar mudah dipahami, maka langkah-langkah anlisis data yang digunakan dalam penelitian ini adalah Analysis Interactive Model dari Miles dan Huberman, yang membagi langkah-langkah dalam kegiatan analisis data dengan beberapa bagian yaitu pengumpulan data (data collection), reduksi data (data reduction), penyajian data (data display), dan penarikan kesimpulan atau verifikasi (conclusions). Kebijakan redaksi Kompas TV Makassar dalam menayangkan berita merupakan sorotan utama, Kompas TV Makassar mempunyai slogan atau jargon dimana ia mengatakan "Kompas TV Independen, Terpercaya". Dengan status tersebut, tentu saja penonton dari Kompas TV Makassar, dari segi kuantitas, dalam jumlah yang besar dan bersifat heterogen. Oleh karena itu peneliti menganggap bahwa apa yang menjadi isi dari media ini akan 
memberikan pengaruh yang besar juga bagi para khalayak.

Pada tahap pengumpulan data penulis telah melakukan wawancara, observasi, dan mengumpulkan dokumen berdasarkan kategori yang sesuai dengan masalah penelitian di Kompas TV Makassar. Pada tahap reduksi data penulis tidak melakukan pembuangan data, tetapi menajamkan, menggolongkan, dan mengorganisasi data sehingga dapat menarik kesimpulan melalui verifikasi terhadap Kompas TV Makassar. Pada tahap penyajian data Penulis menyajikan data berupa rundown acara, proyeksi, dan rapat redaksi via whatsApp yang diberikan langsung oleh Kompas TV Makassar. Penulis dapat menyimpulkan bahwa benar adanya pemutaran berita lebih dari sekali di Kompas TV Makassar khususnya di acara Kompas Sulsel yang ditayangkan setiap hari pada pukul 06.00-07.00 WITA.

\section{Hasil Penelitian}

Pada hasil penelitian, peneliti akan menjabarkan hasil wawancara mendalam mengenai kedua rumusan masalah, yaitu kriteria berita yang layak untuk ditayangkan dan alasan redaksi Kompas TV Makassar menayangkan berita yang sama di hari yang berbeda. Dalam perspektif jurnalistik, berita bukanlah sekadar peristiwa yang terjadi, juga bukan sekadar pernyataan seseorang. Beribu peristiwa bisa terjadi setiap saat, dan berjuta orang bisa angkat bicara setiap waktu, namun tentunya tidak semuanya akan layak diberitakan. Hanya sebagian kecil saja yang memenuhi syarat untuk disiarkan atau pun dipublikasikan.

Berita adalah laporan peristiwa (fakta) atau pendapat (opini) yang aktual (terkini), menarik dan penting. Ada tiga unsur yang saling berkaitan yaitu sumber berita (suppliers), organisasi media (processor), dan aundiens (consumers). Biasanya berita tidak hanya memberikan informasi mengenai peristiwa-peristiwa terbaru, tapi kadang-kadang berita juga digunakan untuk memberikan pengaruh kepada masyarakat yang mendengar atau membacanya. Terutama berita mengenai politik, sering sekali masyarakat dipengaruhi pembawa atau penulis berita agar mengikuti arus politik tersebut.

Dari hasil wawancara mendalam didapatkan bahwa kriteria berita yang layak untuk ditayangkan adalah sebuah berita yang memiliki unsur faktual, tidak melanggar aturan jurnalistik yang telah ditetapkan, dan dapat bermanfaat untuk warga Makassar dan sekitarnya. Jurnalis, produser dan editor harus menjalin komunikasi yang baik dan kerjasama yg profesional untuk menciptakan sebuah 
karya jurnalistik yang dapat menarik perhatian khalayak. Berita yang ditayangkan harus memiliki sifat adil atau tidak memihak kepada siapapun, agar dapat menjadi jembatan untuk mendapatkan informasi yang indepen terpecaya.

Dari hasil wawancara mendalam didapatkan bahwa Kompas TV Makassar setuju mengenai berita yang sama dapat tayang lebih dari sekali di hari yang berbeda. Namun dengan pertimbangan dan alasan yang logis. Pertama berita tersebut adalah berita berbayar, kedua berita tersebut memili unsur yang tidak basi, dan ketiga berita tersebut terlalu memakan banyak durasi sehingga membuat produser membagi dua informasi tersebut dan menayangkannya di hari yang berbeda.

Pada umumnya semua media massa tidak terlepas dari yang namanya unsur "ekonomi" dan unsur "politik". Seperti yang telah dijelaskan oleh Shoemaker dan Reese (1996: 173) level keempat dari teori hirarki pengaruh media adalah pengaruh dari luar organisasi media yang bisa disebut juga extra media level. Extra media level adalah pengaruh-pengaruh pada isi media yang berasal dari luar organisasi media itu sendiri. Kompas TV Makassar sering kali menerima tawaran untuk iklan kampanye menjelang pemilhan umum. Tetapi iklan berbeda dengan pemberitaan yang tayang di Kompas Sulsel. Jika di iklan tampak halhal yang positifnya, di pemberitaan bisa saja ditayangkan hal-hal negatifnya. Kompas TV Makassar menerima bayaran apabila ada seseorang atau pihak yang ingin menampilkan atau menayangkan sebuah informasi, walaupun informasi tersebut sebelumnya sudah pernah tayang. Jadi tidak menutup kemungkinan mereka akan tetap menayangkan berita tersebut berulang-ulang kali. Misalnya pada acara "Sapa Sulsel" ada beberapa bintang tamu dan topik yang sama yang sudah beberapa kali tampil diacara tersebut, namun hal itu dapat dipastikan bahwa pihak tersebut sudah bertransaksi terlebih dahulu kepada pihak Kompas TV Makassar dengan syarat harus membayar sesuai budget yang telah ditetapkan.

Kompas TV Makassar membentuk konsepsi atau posisi seseorang dalam menafsirkan realitas yang mereka perlihatkan sesuai dengan tag line yang mereka miliki yaitu "Independen Terpercaya". Seperti yang telah dijelaskan oleh Shoemaker dan Reese (1996: 221432) level yang terakhir pada teori hirarki pengaruh adalah level pengaruh ideologi pada konten media. Dalam level ini menjelaskan tentang ideologi yang 
diartikan sebagai kerangka berpikir tertentu yang dipakai oleh individu untuk melihat realitas dan bagaimana mereka menghadapinya. Pembahasan pada level ini juga mempelajari hubungan antara pembentukan sebuah konten media, nilainilai, kepentingan dan relasi kuasa media.

Kompas TV Makassar tetap akan setia pada jargonnya yaitu "Independen Terpercaya". Kerena pihak Kompas TV Makssar tidak pernah memihak kepada seseorang. Misalnya sebuah informasi mengenai adanya korupsi yang terjadi dipekerja pemerintah, dan belum diketahui oleh masyarakat. Kompas TV Makassar tidak pernah melihat jabatan, kasta atau kekuasaan apa yang dimiliki oleh seseorang tersebut. Apabila berita atau informasi tersebut sudah sampai ketangan Kompas TV Makassar informasi tersebut akan tetap ditayangkan walaupun dari pihak yang akan diberitakan meminta untuk tidak ditayangkan.

\section{Kesimpulan}

1). Kompas TV Makassar setuju mengenai berita yang sama dapat tayang lebih dari sekali di hari yang berbeda.Kompas TV Makassar sering kali menerima tawaran untuk iklan kampanye menjelang pemilhan umum. Tetapi iklan berbeda dengan pemberitaan yang tayang di Kompas Sulsel.
2). Kompas TV Makassar menerima bayaran apabila ada seseorang atau pihak yang ingin menampilkan atau menayangkan sebuah informasi, walaupun informasi tersebut sebelumnya sudah pernah tayang. Jadi tidak menutup kemungkinan mereka akan tetap menayangkan berita tersebut berulangulang kali.

3). Kompas TV Makassar membentuk konsepsi atau posisi seseorang dalam menafsirkan realitas yang mereka perlihatkan sesuai dengan tag line yang mereka miliki yaitu "Independen Terpercaya”.

4). Kompas TV Makassar tetap akan setia pada jargonnya yaitu "Independen Terpercaya". Kerena pihak Kompas TV Makssar tidak pernah memihak kepada seseorang.

5). Kompas TV Makassar tidak pernah takut akan pendapat khalayak apabila mereka memutar kembali berita yang telah tayang. Karena menurut mereka berita yang tayang kembali adalah berita yang memiliki alasan kuat bahwa berita tersebut harus ditayangkan kembali. Entah itu untuk mengingatkan kembali sebuah peristiwa kepada publik, berita berbayar, untuk memenuhi jam tayang, maupun berita tersebut adalah berita yang dibagi 
dua informasinya namun memiliki gambar dan judul yang sama.

\section{Saran}

1). Kompas TV Makassar harus tetap konsisten berpegang teguh pada ideologi yang telah ada. Karena ideologi adalah jati diri yang menjadikan Kompas TV Makassar berbeda dengan media lainnya.

2). Kompas TV Makassar harus tetap konsisten memberikan pendapat yang kritis, tegas, dan lugas, agar sekaligus menyuarakan aspirasi rakyat secara terbuka, tanpa adanya sesuatu yang ditutup-tutupi, sesuai dengan jargon yang mereka punya yakni "Independen Terpercaya".

3). Dengan segala bentuk kebijakan yang ada, Kompas TV Makassar diharapkan terus berupaya meningkatkan kualitas, yakni dengan mengadakan evaluasi, baik secara substansi ataupun cara penulisan.

4). Diharapkan melalui penelitian selanjutnya, dapat dihasilkan informasi baru dan alternatif solusi terkait kebijakan redaksi Kompas TV Makassar dalam menayangkan berita, sehingga perusahaan media massa eletronik khususnya televisi dapat menangani permasalahan yang ada di perusahaan terkait dengan kebijakan redaksi.

5). Penelitian yang akan datang dalam pengambilan data primer maupun sekunder tidak hanya dengan "kira-kira atau kayaknya atau sepertinya”, perlu dengan observasi lapangan dan wawancara secara mendalam melalui panduan wawancara ke responden sehingga hasil analisis yang diperoleh menjadi komprehensif.

\section{Daftar Pustaka}

Cangara, Hafied. 2005. Pengantar Ilmu Komunikasi. Jakarta: PT Raja Grafika Persada

Djamal, Hidajanto dan Andi, Fachruddin. 2011. Dasar-dasar Penyiaran : Sejarah, Organisasi, Operasional, dan Regulasi. Jakarta: Kencana Prenada Media Grup

Iskandar, Deddy. 2005. Jurnalistik Televisi: Menjadi Reporter Profesional. Bandung: PT Remaja Rosdakarya

Miles, Matthew B dan A, Michael Huberman. 2007. Ananlisis Data Kualitatif. Jakarta: UI Press

Rivers, William L dan Jay, W Jensen Theodore Peterson. 2012. Media Massa dan Masyarakat Modern. Edisi kedua. Jakarta: Kencana Prenada Media Grup

Sugiono. 2012. Metode Penelitian Kuantitatif, Kualitatif, dan R\&D. Jakarta: Rajawali Pers 
Shoemaker, Pamela J dan Stephen, D Reese. 1996. Theories of Influences on Mass Media Content. USA: Longman Publisher

Tohir, Muhammad. 2013. Kebijakan Redaksional Surat Kabar Republika dalam Menentukan Berita yang dipilih Menjadi Headline. Jakarta: UIN Skripsi
Wibowo, Fred. 1997. Teknik Produksi Program Televisi. Yogyakarta: Pinus Bookk Publisher E-File Kompas TV Makassar. 